\title{
Bożena Mrowiec*
}

\section{Plastic pollutants in water environment}

\section{Zanieczyszczenia z tworzyw sztucznych w środowisku wodnym}

\author{
*University of Bielsko-Biala, Institute of Environmental Protection and \\ Engineering, Faculty of Materials, Civil and Environmental Engineering, \\ Willowa 2, 43-309 Bielsko-Biala, Poland, e-mail:bmrowiec@ath.bielsko. \\ pl, tel.33 8279181
}

Keywords: plastic pollutants, microplastics, water environment, ecological effects

Słowa kluczowe: zanieczyszczenia z tworzyw sztucznych, mikroplastiki, środowisko wodne, efekty ekologiczne

\begin{abstract}
Nowadays, wide applications of plastics result in plastic waste being present in the water environment in a wide variety of sizes. Plastic wastes are in water mainly as microplastics (the size range of $1 \mathrm{~nm}$ to $<5 \mathrm{~mm}$ ). Microplastics have been recognized as an emerging threat, as well as ecotoxicological and ecological risk for water ecosystems. In this review are presented some of the physicochemical properties of plastic materials that determine their toxic effect on the aquatic environment. Wastewater treatment plants (WWTPs) are mentioned as one of main sources of microplastics introduced into fresh water, and rivers are the pathways for the transportation of the pollutants to seas and oceans. But, effluents from tertiary wastewater treatment facilities can contain only minimally microplastic loads. The issue of discharge reduction of plastic pollutants into water environment needs activities in the scope of efficient wastewater treatment, waste disposal, recycling of plastic materials, education and public involvement.
\end{abstract}

() IOŚ-PIB

\section{INTRODUCTION}

Production and distribution of plastics continue to increase both in developed and developing countries. From the 1950s, the plastic production increased almost 200 times, from 1.5 million tons to over 300 million tons in 2015 [Laglbauer et al. 2014, Van Cauwenberghe et al. 2015, Pinheiro et al. 2017, Wright and Kelly, 2017]. Plastics are lightweight, highly durable, strong and cheap [Solomon and Palanisami 2016]. They are used in a great number of applications, ranging from household and personal goods, clothing and packaging to construction materials.

The wide applications of plastics result in plastic waste being present in the environment in a wide variety of sizes. The smallest forms are called microplastics (MPs). These occur in the environment as 'microplastics by design' (primary microplastics) or result from the degradation of larger plastic waste (secondary microplastics) [Van Cauwenberghe et al. 2015, Alomar et al. 2016]. One major aspect of plastic pollutants is the occurrence of microplastics in the aquatic ecosystems. It was estimated that the accumulative potential of plastics in the marine environment will be in the range of 250 million tons by 2025 [Wright and Kelly, 2017].

\section{Streszczenie}

Obecne, szerokie zastosowania tworzyw sztucznych powodują, że plastikowe odpady obecne są w środowisku wodnym w szerokim zakresie rozmiarów. Występują w wodzie głównie jako "mikroplastiki" (zakres wielkości od $1 \mathrm{~nm}$ do $<5 \mathrm{~mm}$ ). Zanieczyszczenia z tworzyw sztucznych traktowane są jako nowe zagrożenie, w tym ekotoksykologiczne i ekologiczne zagrożenie ekosystemów wodnych. W tym artykule przeglądowym przedstawiono niektóre właściwości fizyko-chemiczne tworzyw sztucznych, które decydują o ich toksycznym wpływie na środowisko wodne. Oczyszczalnie ścieków są wymieniane jako jedne z głównych źródeł zanieczyszczeń z tworzyw sztucznych wprowadzanych do wód, a rzeki traktowane są jako drogi transportu tych zanieczyszczeń do mórz i oceanów. Jednak odpływy z trzystopniowych procesów oczyszczania ścieków mogą zawierać tylko minimalnie ładunki mikroplastików. Kwestia ograniczenia emisji zanieczyszczeń z tworzyw sztucznych do środowiska wodnego wymaga działań w zakresie efektywnego oczyszczania ścieków, usuwania odpadów, recyklingu tworzyw sztucznych, edukacji i zaangażowania społecznego.

Plastic pollutants were first detected in the North Atlantic in the 70's of the last century. At present, the most prominent types of waste occurs in fresh water, deep ocean environment and sediments in the form of spheres, pellets, irregular fragments and fibres [Alomar et al. 2016]. It is estimated that $70-80 \%$ plastic contaminants originate from land-based sources and they are transported by rivers to seas and oceans [Andrady 2011, Jambeck et al. 2015, Avio et al. 2016, da Costa et al. 2016, Peters and Bratton 2016]. The threats posed by plastics to water environment were initially ignored for long time, but now these have gained interest among many researchers. Recently, microplastics have been recognized as an emerging threat, as well as ecotoxicological and ecological risk for water ecosystems [Avio et al. 2016].

Broad discussion of the pollutant problem has resulted in an increase in the awareness of the harmful environmental effects of these pollutants in the cosmetic and beauty products industries. Some cosmetic industries have replaced these components with more environment friendly alternatives. Some states in USA like California, New York, New Jersey, and Illinois have proposed a 
ban on the use and sale of cosmetics containing microplastics [Carr et al. 2016]. Some plastics such as aliphatic polyester and bio-polymer have the tendency to undergo complete degradation or mineralization (into carbon dioxide or methane) in the water environment, but the cost of production of these polymers is very high [Solomon and Palanisami 2016].

The aim of this paper is to review the research data in the fields of physico-chemical properties, transport and influence of plastic pollutants to aquatic environment.

\section{PHYSICO-CHEMICAL PROPERTIES OF PLASTIC POLLUTANTS}

Plastics are present in the water environment in a wide variety of sizes, ranging from micrometres to metres [Van Cauwenberghe et al. 2015]. As mentioned in the introduction, plastic pollutants are classified mainly as primary and secondary microplastics (MPs). Primary MPs are polymers intentionally manufactured in a microscopic scale (the size range of $1 \mathrm{~nm}$ to $<5 \mathrm{~mm}$ ) through the process of extrusion or grinding, to be used as raw materials for other products (e.g., plastic pellets and microbeads associated with industrial spillages and used in cosmetics, cleaning products or drug vectors) [Cole et al. 2011, Hidalgo-Ruz et al. 2012, Van Cauwenberghe et al. 2015, Alomar et al. 2016, Peters and Bratton 2016, Solomon and Palanisami 2016, Graca et al. 2017]. The secondary MPs are formed during the degradation of macroplastics due to the mechanical, photolytic and/or chemical degradation of bigger plastic fragments in water environment and often result in fragmented pieces or fibres [Van Cauwenberghe et al. 2015, Alomar et al. 2016, Peters and Bratton 2016, Graca et al. 2017, Lambert et al. 2017]. The smallest particles are defined as nanoplastics, as the contaminants are of the size of nanoparticles (<100 nm).

The physical and chemical properties of plastic pollutants, including particle size, shape, surface area, crystallinity, polymer type and chemical additives, determine their ecotoxicity [Lambert et al. 2017]. There are 7 main classes of produced plastics: polyethylene (PE), polypropylene (PP), polyvinyl chloride (PVC), polystyrene (PS), Polyamide (PA), polyurethane (PUR) and polyethylene-terephthalate (PET) [Andrady 2011, Laglbauer et al. 2014, Avio et al. 2016, Solomon and Palanisami 2016]. Polymer crystallinity (structure of polymer chains) affects the physical properties of plastic pollutants such as density and permeability. This property may change with the polymers' degradation process and result in the formation of crystallites, which might differ in toxicity compared to the parent plastics [Lambert et al. 2017]. The specific gravity of the plastics range from 0.91 (PE) to 1.5 (PA) $\mathrm{g} / \mathrm{cm}^{3}$ [Andrady 2011, Avio et al. 2016, Solomon and Palanisami 2016]. Therefore, the plastic pollutants depending on the type of material and particle size can sink to the bottom sediments or float on the water surface. Apart from the main monomer, plastics contain a variety of organic plastic additives added during their manufacturing (i.e., initiators, catalysts, solvents, antimicrobial agents, surfactants, plasticizers, flame retardants, lubricants, dispersant, antistatic agents, nanoparticles, fillers, fragrances and pigments) [da Costa et al. 2016, Lambert et al.
2017, Wright and Kelly, 2017]. Plastic particles have hydrophobic nature; therefore, they can adsorb other dangerous organic and inorganic contaminants such as: endocrine-disrupting compounds, pharmaceuticals, polychlorinated biphenyls (PCBs), polycyclic aromatic hydrocarbons (PAHs), polybrominated diphenyl ethers (PBDEs), personal care products and heavy metals from the surrounding water and so on [Hidalgo-Ruz et al. 2012, Carr et al. 2016, Ma et al. 2016, Solomon and Palanisami 2016, Graca et al. 2017, Pinheiro et al. 2017, Wright and Kelly, 2017]. The degradation process of synthetic plastic pollutants is slow; therefore, the particles persist for a very long time in the water environment and become available to water organisms [Laglbauer et al. 2014]. In aquatic environment, the degradation process can occur as: biodegradation (action of living organisms - microbes), photodegradation (action of light - sunlight), thermos-oxidative degradation (slow oxidative breakdown at moderate temperatures) and hydrolysis (reaction with water) [Andrady 2011, Ivar do Sul and Costa 2014]. Bioavailability of plastic particles increases with decreasing size, making them easily available to smaller trophic organisms [Setala et al. 2014, Chae and An 2017, Pinheiro et al. 2017]. Nanoplastics are more likely to pass biological membranes and affect the functioning of cells, including blood cells and photosynthesis [da Costa et al. 2016]. Chae and An [2017] presented that nanoparticles (100 $\mathrm{nm}$ ) after a 45-min exposure remain in the body of $M$. edulis and Crassostrea virginica longer than microplastics, and can be transported to the digestive organs. Particles' shapes determine the interaction of plastic pollutants with biological system. A more irregular shape may attach more readily to internal and external surfaces and exert a greater toxic effect [Lambert et al. 2017].

\section{SOURCES AND TRANSPORT PATHS}

Plastic pollutants enter the water environment from various sources. Among them can be distinguished: wastewater treatment plants, cargo shipping, fisheries, human waste from beaches and urban runoff [Cole et al. 2011, Stolte et al. 2015, Peters and Bratton 2016, Alomar et al. 2016, Michielssen et al. 2016, Solomon and Palanisami 2016, Graca et al. 2017, Mintening et al. 2017, Wright and Kelly, 2017]. Often, wastewater treatment plants (WWTPs) are mentioned as the main sources of microplastics in aquatic environment. Microplastics, for example, from cosmetics and other plastic waste, end up at the municipal WWTPs [da Costa et al. 2016]. The content of microplastics in WWTP influent vary in the range of $10^{4}$ to $10^{5}$ microplastics $/ \mathrm{m}^{3}$ and the their incomplete removal (70-100\%) during the treatment process can result in pollution in the receiving water. Mintening et al. [2017] detected in the effluent from 12 WWTPs microplastics with quantities ranging from 0 to $5 \times 10^{1}$ microplastics $/ \mathrm{m}^{3}$ in the size $>500 \mu \mathrm{m}$ and $1 \times 10^{1}$ to $9 \times 10^{3}$ microplastics $/ \mathrm{m}^{3}$ in the size $<500 \mu \mathrm{m}$. Synthetic fibres were found in quantities from $9 \times 10^{1}$ to $1 \times 10^{3}$. Good efficiency of wastewater treatment in the range of plastic pollutants removal was stated by Talvitie et al. [2015]. The microplastic load after the treatment process was found to be an average of 8.6 particles and 4.9 fibres per litre of wastewater. Despite the high efficiency of wastewater 
treatment, the average fibre content was 25 times higher and the particle content was 3 times higher in the effluent compared to the receiving water body. Therefore, the authors suggested that WWTPs can be considered to play an important role for receiver pollution. But, there are researches who do not confirm a direct link between plastic contaminants in rivers and WWTPs [Carr et al. 2016, Estahbanati and Fahrenfeld, 2016]. It should be noted that most rivers with a high rate of plastic waste are located close to large urban centres. Carr et al. [2016] stated, that microplastic particles are removed in the primary treatment zones via solids skimming and sludge settling processes and they suggested that effluent discharges from both secondary and tertiary wastewater treatment facilities can contain only minimal microplastic loads discharged to the surface water. The efficiency of wastewater treatment process can be on the level of $99.9 \%$ removal, leading to an average discharge of one microplastic for every $1400 \mathrm{~L}$ of effluent. Tertiary gravity sand filtration and membrane filtration as part of anaerobic membrane bioreactor treatment provide substantial additional removal of microplastics [Michielssen et al. 2016]. Also, low microplastic load in the final effluent of WWTPs (0.21-1.5 microplastics/L) was stated by Ziajahromi et al. [2017]. The authors suggest, that synthetic fibres from clothing are the bigger issue than microplastic beads from personal care products, because they were not completely removed even after advanced treatment processes. A single polyester fibre shirt releases 1900 fibres in a single washing [Stolte et al. 2015]. Moreover, the authors stated a dynamic increase during summer season in the Baltic Sea water, which suggests that tourist activity could be a major entry path for potential synthetic fibres as well.

The above results indicate that plastic contaminants can be effectively removed from wastewater, provided that the technological process is applied in a proper manner. In addition, it should be noted that plastic contaminants entering wastewater treatment facilities, for the most part are different from those that are commonly disposed of in storm drains, beaches, oceans, and fresh water locations such as lakes and rivers. Therefore, the primary sources of microplastics in water environments should be identified with discarded consumer packaging (containers, bags, bottles) and industrial waste [Carr et al. 2016]. These sources of plastic pollutants require thorough analysis and action to reduce the waste discharge into the aquatic environment.

\section{MICROPLASTICS IN WATER ENVIRONMENT AND IMPACT ON ORGANISMS}

The occurrence of plastic pollutants in water results in loss of aesthetic perception and environmental value. They decrease economic repercussions for the tourism and cause significant biological concerns for water organisms [Avio et al. 2016].

Besides, the factors such as size, density, shape, charge, colour, aggregation and abundance of plastic particles affect their bioavailability [Van Cauwenberghe et al. 2015]. Many water organisms (i.e., crustaceans, molluscs, fish, birds, and mammals) confuse microplastics with food or selectively feed on them in place of food. It results in an impact on the organisms of all trophic levels. For example, Li et al. [2016] investigated microplastics in mussels (Mytilus edulis) from 22 sites of coastlines in China. The number of total microplastics varied from 0.9 to 4.6 particles $/ g$ and from 1.5 to 7.6 particles/individual. The most common microplastics were fibres. The proportion of microplastics that were less than $250 \mu \mathrm{m}$ in size ranged from $17 \%$ to $79 \%$ of the total microplastics. Avio et al. [2015] found microplastics in fish species: Sardina pilchardus, Squalus acanthias, Merluccius merluccius, Mullus barbatus and Chelidonichthys lucerna. The plastic particles were isolated by extraction method and quantified in stomach and liver, and their presence in the hepatic tissue was also confirmed by histological analyses. The dominant plastic $(65 \%)$ in the stomachs of fishes was polyethylene. The occurrence of plastic particles in body of harbour seals from the Netherlands were investigated by Bravo Rebolledo et al. [2013]. The authors stated that in the samples of 107 stomachs and 100 intestines, the incidence of plastics was respectively $11 \%$ and $1 \%$. Younger animals, up to 3 years of age, were more exposed to ingestion of plastics.

The reduction of plastic particles to a micro- and nano-scale can lead to an increase in their sorption properties and in transport of the harmful compounds from plastics into water organisms [Ma et al. 2016, Graca et al. 2017]. Ma and co-workers [2016] stated an additive effect of toxicity of 50-nm nanoplastics and phenanthrene to $D$. magna. They showed, that during a 14-day incubation, the presence of nanoplastics significantly enhanced bioaccumulation of phenanthrene-derived residues in daphniid body and inhibited the dissipation and transformation of phenanthrene in the medium. For microplastics, $10-\mu \mathrm{m}$ in size effects of the analysed processes were not so significant.

Microplastics floating in water have the tendency of providing raft substrates for various epifauna and microbes (i.e., bacteria, algae, diatoms, barnacles, hydroids, tunicates) and transporting them to areas where they were not existing before [Solomon and Palanisami 2016].

Although many publications on the occurrence of microplastics in the aquatic environment are currently being published, there is only general information on the health risk associated with ingestion of the pollutants. Plastic particles can result in negative effects, such as blockage of the intestinal tract and abrasion in small organisms. Microplastic indigestion could also decrease energy reserves, inhibition or reduction of feeding/ filtering activity, disrupt the endocrine and reproductive systems, translocation to the circulatory system, and increase toxic load in smaller organisms [Wright et al. 2013, Laglbauer et al. 2014, Van Cauwenberghe et al. 2015]. Plastic particles can cause alteration of immune system parameters and loss of DNA integrity [Avio et al. 2016]. Additional toxic effects of microplastics can also be caused by the wide array of plastic additives and adsorbed substance in aqueous media. The substances can migrate, diffuse or desorb from plastic polymers and cause additional adverse effects [Van Cauwenberghe et al. 2015, Avio et al. 2016, Carr et al. 2016]. Other substances like persistent organic pollutants (POPs) will preferentially partition onto plastics reaching concentrations up to a million times greater than in the surrounding aqueous environment [Andrady 2011, Mason et al. 2016]. For example, Rios and Moore [2007] determined PAHs, 
PCBs, and dichlorodiphenyltrichloroethane (DDT) on plastic waste on ten beaches in the Central and North America. The values of sum concentrations of the substances were: PAHs 39 $-1200 \mathrm{ng} / \mathrm{g}$, PCBs $27-980 \mathrm{ng} / \mathrm{g}$ and DDT $22-7100 \mathrm{ng} / \mathrm{g}$. The researches stated even higher concentrations of the analysed substances in plastic pellets collected from beaches near industrial sites. The highest values were: PAHs $-12 \mu \mathrm{g} / \mathrm{g}$ and DDT $-7.1 \mu \mathrm{g} / \mathrm{g}$. Recently, Wright and Kelly [2017] presented that up to $2.4 \mathrm{mg} / \mathrm{g}$ PAHs and $0.1 \mathrm{mg} / \mathrm{g}$ DDT were stated for plastic pellets sampled from the beaches in China. The ingested plastics may lead to rapid death of water organisms [Graca et al. 2017]. Microplastics may also pose a potential threat to human health through ingesting contaminated seafood [Ziajahromi et al. 2017]. With increasing levels of microplastic content, adverse effects to the health of humans have to be anticipated with the long-term presence and exposure to microplastics [Stolte et al. 2015].

Therefore, more tests, especially field tests are needed to better explain microplastics uptake, translocation and retention or egestion in water species compromising all trophic levels and investigate if the transfer of microplastics across the food web implies bioaccumulation and biomagnification [Alomar et al. 2016].

\section{REFERENCES}

ANDRADY A.L. 2011. Microplastics in the marine environment. Marine Pollution Bulletin 62: 1596-1605.

ALOMAR C., ESTARELLAS F., DEUDERO S. 2016. Microplastics in the Mediterranean Sea: Deposition in coastal shallow sediments, spatial variation and preferential grain size. Marine Environmental Research 115: 1-10.

AVIO C.G., GORBIS., REGOLI F. 2015. Experimental development of a new protocol for extraction and characterization of microplastics in fish tissues: First observations in commercial species from Adriatic Sea. Marine Environmental Research 111: 18-26.

AVIO C.G., GORBIS., REGOLIF. 2016. Plastics and microplastics in the oceans: From emerging pollutants to emerged treat. Marine Environmental Research. Article in press. http://dx.doi. org/10.1016/j.marenvres.2016.05.12

BRAVO REBOLLEDO E.L., VAN FRANEKER J.A., JANSEN O.E., BRASSEUR S.M. 2013. Plastic ingestion by harbour seals (Phoca vitulina) in The Netherlands. Marine Pollution Bulletin 67 (1-2): 200-202.

CARR S.A., LIU J., TESORO A.G. 2016. Transport and fate of microplastic particles in wastewater treatment plants. Water Research 91: 174-182.

CHAE Y., AN Y.J. 2017. Effects of micro- and nanoplastics on aquatic ecosystems: Current research trends and perspectives. Marine Pollution Bulletin 124:624-632.

COLE M., LINDEQUE P., HALSBAND C., GALLOWAY T.S. 2011. Microplastics as contaminants in the marine environment: $A$ review. Marine Pollution Bulletin 62: 2588-2597.

DA COSTA J.P., SANTOS P.S., DUARTE A.C., ROCHA-SANTOS T. 2016. (nano)plastics in the environment - Sources, fate and effects. Science of the Total Environment 566-567: 15-26.

ESTAHBANATI S., FAHRENFELD N.L. 2016. Influence of wastewater treatment plant discharges on microplastic concentrations in surface water. Chemosphere 162: 277-284.

\section{SUMMARY}

There is a need to understand the way in which human attitudes and behaviour can be influenced to reduce the sources of microplastics in the water environment. The issue of plastic pollutants in the water can determine the socio-economic system because they can change the water environment quality for future generation. The accumulation of microplastics along food chain could pose a threat to the food safety and generate serious health implications. Due to the long-life of plastics in water environment, harm to organisms would continue for many decades, even if the discharge of the pollutants suddenly stopped. In order to limit the harmful impact of plastic pollutants on the aquatic environment, different actions are necessary. Very important are activities in the scope of efficient wastewater treatment, waste disposal, recycling of plastic materials, education and public involvement in understanding the problem, integration and harmonization of science disciplines and usage of innovating biodegradable plastics and other alternatives. Moreover, there is need to involve disciplines that can understand the economic and social barriers and effect change behaviour and markets, and evaluate the benefits.

GRACA B., SZEWC K., ZAKRZEWSKA D., DOLEGA A., SZCZERBOWSKA-BORUCHOWSKA M. 2017. Sources and fate of microplastics in marine and beach sediments of the Southern Baltic Sea - a preliminary study. Environ. Sci. Pollut. Res. 24: 7650-7661.

HIDALGO-RUZ V., GUTOW L., THOMPSON R.C., THIEL M. 2012. Microplastics in the marine environment: $A$ of the methods used for identification and quantification. Environ. Sci. Technol. 46: 3060-3075.

IVAR DO SUL J.A., COSTA M.F., 2014. The present and future of microplastic pollution in marine environment. Environmental Pollution 185:352-364.

JAMBECK J.R., GEYER R., WILCOX C., SIEGLER T.R., PERRYMAN M., ANDRADY A., NARAYAN R., LAVENDER LAW K. 2015. Plastic waste inputs from land into the ocean. Marine Pollution Science 347 (6223): 768-771.

LAGLBAUER B.J., FRANCO-SANTOS R.M., ANDREUCAZENAVE M.A., BRUNELLI L., PAPADATOU M., PALATINUS A., GREGO M., DEPREZ T. 2014. Macrodebris and microplastics from beaches in Slovenia. Marine Pollution Bulletin 89: 356-366.

LAMBERT S., CHRISTIAN S., WAGNER M. 2017. Ecotoxicity testing of microplastics: considering the heterogeneity of physico-chemical properties. Integrated Environmental Assessment and Management 13 (3): 470-475. DOI:10.1002/ ieam.1901.

LI J., QU X., SU L., ZHANG W., YANG D., KOLANDHASAMY P., LI D., SHI D. 2016. Microplastics in mussels along the coastal waters of China. Environmental Pollution 214: 177-184.

MA Y., HUANG A., CAO S., SUN F., WANG L., GUO H. 2016. Effects of nanoplastics and microplastics on toxicity, bioaccumulation, and environmental fate of phenanthrene in fresh water. Environmental Pollution 219: 166-173. 
MASON S.A., KAMMIN L., ERIKSEN M., ALEID G., WILSON S., BOX C., WILLIAMSON N., RILEY A. 2016. Pelagic plastic pollution within the surface waters of Lake Michigan, USA. Journal of great Lakes Research. http://dx.doi.org/10.1016/j. jglr.2016.05.009

MICHIELSSEN M.R., MICHIELSSEN E.R., NI J., DUHAIME M.B. 2016. Fate of microplastics and other small anthropogenic litter (SAL) in wastewater treatment plants depends on unit processes employed. Environ. Sci.: Water Res. Technol. 2:1064-1073.

MINTENING S.M., INT-VEEN I., LÖDER M.G., PRIMPKE S., GERDTS G. 2017. Identification of microplastic in effluents of waste water treatment plants using focal plane array-based micro-Fourier-transform infrared imaging. Water Research 108: 365-372.

PETERS C.A., BRATTON S.P. 2016. Urbanization is a major influence on microplastic ingestion by sunfish in the Brazos River Basin, Central Texas, USA. Environmental Pollution 210: 380-387.

PINHEIRO C., OLIVEIRA U., VIEIRA M. 2017. Occurrence and impacts of microplastics in freshwater fish. Journal of Aquaculture and Marine Biology 5, (6): 00138. DOI:10.15406/ jamb.2017.05.00138.

RIOS L.M., MOORE C. 2007. Persistent organic pollutants carried by synthetic polymers in the ocean environment. Marine Pollution Bulletin 54 (8): 1230-1237.

SETALA O., FLEMING-LEHTINEN V., LEHTINIEMI M. 2014. Ingestion and transfer of microplastics in the planktonic food web. Environmental Pollution 185: 77-83.
SOLOMON O.O., PALANISAMI T. 2016. Microplastics in the marine environment: Current status, assessment, methodologies, impacts and solution. Journal of Pollution Effects and Control 4 (2) http://dx.doi.org/10.4172/23754397.1000161

STOLTE A., FORSTER S., GERDTS G., SCHUBERT H. 2015. Microplastic concentrations in beach sediments along the German Baltic coast. Marine Pollution Bulletin 99: 216-229.

TALVITIE J., HEINONEN M., PÄÄKKÖNEN J.P., VAHTERA E., MIKOLA A., SETÄLÄ O., VAHALA R. 2015. Do wastewater treatment plants act as potential point source of microplastics? preliminary study in the coastal Gulf of Finland, Baltic Sea. Water Science and Technology 72 (9): 1495-1504.

WRIGHT S.L., THOMPSON R.C., GALLOWAY T.S. 2013. The physical impacts of microplastics on marine organisms: A review. Environmental Pollution 178: 483-492.

WRIGHT S.L., KELLY F.J. 2017. Plastic and human health: A micro issue? Environ. Sci. Technol. 51: 6634-6647.

VAN CAUWENBERGHE L., DEVRIESE L., GALGANI F., ROBBENS J., JANSSEN C.R. 2015. Microplastics in sediments: A review of techniques, occurrence and effects. Marine Environmental Research 111: 5-17.

ZIAJAHROMI S., NEALE P.A., RINTOUL L., LEUSCH F.D. 2017. Wastewater treatment plants as a pathway for microplastics: development of a new approach to sample wastewater-based microplastics. Water Research 112: 93-99. 